-I henrtily agree with Drs. Ochsmer and Grunt who do not, as a rule, break down adlesions to remove the appendix in acute ases; but who first drain, then remove the appendix later. Adhesions are life-snvers and should not be disturbed merely for the purpose of removing un organ which can be removed without danger subsequently.

Dr. W. T. Rey xolos, Kansas City, Mo.: Recent studics of the blood have taught us that in loculized abscesses there has been an antogenous vaccinntion which lias brought about a grent resistance. In peritubal nbscesses we never think of draining the nbscess and leaving a leaky tube. The sume proposition confronts us in the vast majority of instances in Joenlized appendicenl abscesses. It is not usually hard to find a line of elenvage which makes it comparatively ensy to divide the adhesions and find the disensed appendix. I am heartily in areord with the essayist and hine found in my own experience a greatly reluced mortality in fearlessly draining from the bottom of the pelvis.

Dr. Van Bures linotr, Sioux City, la.: Not many years ngo at a meeting of this society we listened to claims that no appendicitis patient slould be operated on. So $1 \mathrm{am}$ not surprised to find men still claiming that a leaking, stinking nppendix should be left in an ublomen to make the patient us unconfortable as possjble. Reform loes not always come at once, but slowly and usunlly through laard knocks. 13ut as fur as my own experience is concerned, $J$ am removing this appendix for a diflerent reason. Some seem to think that the removal of the appendix at the time of the original operation is merely a matter of cosmetics-not that there is any reason to think that its removal can do the patient any good. But that is not the point. We remove the appendix to lower the mortality; and my mortality has been jeduced from 8 to 1 per cent. in these cases; and these men will have to show me a lower mortulity thin 1 per cent. in these abs:ess canes before I will agree with them.

Sioux City is a small town. but we are near Missouri; and we slanll be glad to show anybody wlo doubts the kind of work we are doing there. Two or three gool inen in Omula and in Kansas City, Dr. MacLuren. of St. Paul, and other men throughout the middle west, are doing this kind of work. Dr. Ross tells me he lins not loft an appendix in the abdomen in four yeurs and that in wearly every one of these cases he has described to you of subphirenic abscess, that came to post-mortem, he found there was always un appendix left. It is a fact that patients will not die from peritonitis; we did uot have a death from peritonitis in this series of cases. 1 believe most cases of circumscribed abscess will die of sepsis rather than peritonitis, and they will be more apt to die of sepsis if drainage is superficial.

1 am surprised to find so many different hidden pus pockets scattered through the lower portion of the pelvic cavity. These could not be reached by incomplete surgery. In my exporience such surgery leads to an umecessurily high mortality.

It is nll nonsense to sny that after the abdomen is opened you will decide whether or not you will jemove the uppendix, beciluse no man ean decide whether an appendix will come out harrl or ensy, if it is more or less tungled with aulhesions.

No one should undertake this operation who is going to oceupy thirty minutes in finding the uppendix and getting it out after the peritoneun is opened; and if he does start to remove it and bucks out because it is a little hard, he has exposed his patient to all the trumma he would get any way.

Dr. Ochoner says if he thinks his patient is going to die. he leaves the appendix. IBut this is just the class of cases in which we remove them.

Dr. Cinonge G. Ross, Philadelphia: I ngree with what Dr. Knott has said. I have not leit an appendix in four years, and as yet $I$ have had no occasion for regret.

I believe that the mortulity in these acute appendicular locnlized abscesses is not so much due to the infection of the peritoneum as it is to the fact that the infection gets behind the endothelial coat of the peritoneum. It is this type of retroperitonenl infection that is attended by n very high mortality for the reason that the retroperitoneal space cammot be drained.

\section{TUMORS OF THE MESENTERY}

\section{WITIL A BREPORT OF FOUR CASES * \\ IUUBEIR' A. ROYSTJER, A.B., M.D. \\ IBALICII, N. C.}

In spite of the contributions that have appeared from time to time coneerning mesenteric tumors and the inter est manifested in certain reported cases. there is god reason to believe that these growths have been neglented and that they have not received the systematic attention to which their importance entitles them. That they ald (omparatively uncommon is admitted; but this woll seem to supply a stronger reason for their careful studi When one has to depend on text-books or even on rendily. available perioilic literature, one must encounter ser the difficulty in the management of such enses. Tnder flll, clearest conditions. they require judgment and, above
experience which may be gained at the cost of stumb on them unawares.

In this paper an attempt will be made, first, to elassill the existing pathologic and clinical knowledge of thill subject; second, to record some personal cases, which pill lear on questions of diagnosis and operative metho the and third, to review the important articles found in recent literature. It will not be necessary to ${ }^{\circ}{ }_{190 \%}$ historic detail, since Douglas ${ }^{1}$ covered the facts in 1906 .
and both Vance ${ }^{2}$ and Bowers restated them in 1906 .

\section{ORIGIN}

Our topic includes only those tumors which origing the in the mesentery itself and not the so-called retropestile toneal growths. 'The latter may arise from any tisthe hehind the peritoneum and push forward between $w$ al layers of the true mesentery. They have served in a to confuse the classification.

In order to appreciate the situation and character of these tumors, it is well enough briefly to consider fold mesentery, its development and its structure. Any the of peritoneum comnecting a part of the intestine to posterior wall of the abdominal cavity may be called mesentery, though this unqualified term is generally employed to designate the special portion of the me comp brane attaclied to the small intestine (mesenterium com muno).

In the development of the embryo, as the right alle the left halves of the boly cavity come toward each oflete the early connective tissue is compressed into a primitist mesentery, which is attached to the whole length of $\mathrm{Intes}^{\mathrm{s}}$ alimentary tube, from the stomnch to the anus. In yet $^{\text {ts }}$ tine and peritoneum are developed together, two layen of the serous membrane investing the bowel. Wo fully formed the mesentery is fan-shaped, its length of insertion being many times that of its fixed attaclinente It runs obliquely from left to right, extending from to second lumbar vertebra, crossing the spinal colum $m^{n^{n}}$ the right sacro-iliac joint. Its root, or point of orig of the two layers, is 6 inches in length, while the $e^{n^{\text {yet }}}$

intestinal edge is 21 feet long (Gray).
Between the two layers of peritoneum that constitute the mesentery, run arteries, veins, lymphatic ves $\mathrm{S}^{\mathrm{e}} \mathrm{fl}^{10}$ lacteals, and nerves-all imbedded in connective tissior and fat. 'These enter and leave through the poster ded space, where the intestine is not completely surround by serous membrane. It is readily seen, therefore, th

* Read in the Scetion on Surgery of the Amerlean Medical clution. at the slxty-Second Annual Session, held nt Los An Junu, 1911.

1. Douglas: Surgical Ilseases of the Abdomen.

3. Bowers : Avn. Surg., 1906, Ix」v, 892. 
tumors of the mesentery must be largely of the meso-

\section{Growths of vilikines}

Cysts are by the mesentery may be solid or cysicic. their contents far the more common and, according to hydatid or dermo either serous, chylous, hemorrhagic, nant. The formoid. Solid tumors are benign or maligthe latter sarcomer are lipoma. myxoma and fibroma and greatly outnumber It is very probnble that the lipomata tion is said to talse other's, but sarcomatous degeneraof the simpler no place sooner or later in the majority are very often peoplasms. The lipomata and fibromata pathology of thene to attain an enormous size. 'The similar growths in others differs in nowise from that of

\section{Ijittle can Ersotogy}

little is known said of the etiology, because, incled, congenital in of it. Tndoubtedly, some growths are time before thering, and certainly many exist for a long the influence are recognized. It is in such cases that may light up of tramma is given credence, for an injury Bachmann or eall attention to a preexisting growtl. a boy of 9 refers to this fact in his report of the case of fallen across a who, eight weeks before examination. had two months a barrel and on whom an autopsy was done tiple fibromata later, which showed large masses of mulhaving noted the in the mesentery. He quotes Pean as for years, only to bact that large tumors mav be present sort of traumatio bevealed in their final stage by some factors in the hood, however, we veryce of these growths. In child-

\section{Before diocusing of casis}

well to put on ling more practical questions, it will be whis paper. By record the cases which form the basis of which sometimes virtue of those peculiar coincidences monis fell to my out in our work, four mesenteric months, the last lot last year, within the space of six order more than three coming all within a period of a of their occurjence. 'l'hey are presented in the aged $1 .-D_{\text {ermoid }}$ aber

aged about 40 , of fir Cyst of the sigmoid Mesocolon.- Mrs. Y., severe We $_{8}$ befor frail constitution, mother of three children, quick abdominal conting under observation, had $a$ sudden 'Thekly transferred bain, breginning in the right iliac region, but a ver was a histored to the left; she vomited and had fever. in the before resery of previous colies and of one attuck nearly in the bladder regiong this, except that the pain was chicty ture Enination. - On.

ture was 101; the the first visit, March 28, 1910, tempera. down. but partieure was pain and tenderness all over the same; very little dilarly at the border of the left rectus. low lighe day, the tendertention. At the second visit, evening of interf (104); local sigs was much less, but the fever much passed ance should signs diminishing. It was agreed that no fever away. By April andsed until the acute process lind condition pain; the abdom 12 there was a practical subsidence of right was good. felt; lower iliac good. Local symptoms were centering in the and this mass wasion, where a very sensitive mass conld be pinx. gave indistinct easily palpated on bimanual examination it ventured considered im of nny listory lending to that affection, operation improbnble. No definite statement was incision.

elsion. A mex Iospital, April 13, 1910: right rectus

4. Bachmana: Inaus of adiesions was encountared around the Inaugural Elssertution, Lrianger, 1408. bladder, uterus and cecum; the sigmoid flexure had been drawn far over to the right and within the folds of its mesentery. near the intestinal border, was found a somewhat flattenad cyst of the size of an orange. In the process of enucleation the cyst was ruptured and the character of its contents-teeth, hair and bone embedded in a mulsy material-was determined. The mesenteric vessels were uninjured and no ligatures were required, only whipping over the edges with catgut. The uterus, tubes and ovaries were normal; the nppendix, being engaged in the allesions, was removed. A drainage tube with tape was inserted into the lower angle of the wound.

The pationt lad a very pleasant recovery and is in better health than she had been for several years. The specimen (Fig. l) is a typieal dermoid eyst, containing hair and a wellmarked alveolar proeess with several perfect teetl.

Dermoid cysts of the mesentery are, of conrse, very rare. According to Bell and Yeoman, ${ }^{5}$ up to 1908 about 150 cases of mesenteric cysts were found scattrod throughout the literature; but of all these cases, thire are certainly not more than twenty described as dermoids. These writers report a dermoid of the jejumal mesentery in a woman of 24 , which was felt as a large, round, tender and movable "lump" between the uterus and the bladder, and thomght to be a fibromyoma of the uterus. It was found Jying between the folds of the mesentery with a loop of lowel curving around it. Attempts at enucleation being unsuccessful, the entire cyst was excised, the hole in the mesentery closed and a loop of bowel resected. The patient made a tedions recovery. Ehler ${ }^{6}$ also operated successfully on a patient, ager 22, for a dermoid cyst of the descending colon, which had to be dissected willely and was associated with another similar cyst at the hilum of the kidney. These two are the only other dermoids of the mesentery reported since $190 \%$, and bring the number to not more than twenty-three, including the case berewith presented.

Dermoids, wherever found, have their origin in fetal inclusion or implantation from the ectoderm and are, therefore, congenital growths. They belong to the class of teratomata. The mesenteric forms are commonly derived as post-rectal dermoids, which may develop at any point along the infolding process. They do not usially give clinical signs until long after infantile life and are more apt to contain teeth than are dermoids in any other situation.

Case 2.-Sarcoma of Sigmoid Hesocolon.-M. A. F.. male, colored, aged 50, for several months had been troubled with ablominal pain and tendermess. At first his bladder was irritable; lately his rectum had been troubling him. He was sent in with a diagnosis of bladder tumor. He laad lost about 30 pounds in weiglit.

Examination.-In appearance he was emaciated and holloweyed. The abdomen showed a hard nodular tumor, low down, near the mid-line, but chiefly to the loft: on rectiul examination it was found somewhat movable and apparently lying on the rectum. It had exactly the "fecl" of a uterine fibroid in a woman.

Operation.-St. Agnes Hospital, Sept. 1. 1010: a low left rectus incision. About a pint of serous filid was in tho cavity. The large tumor (Fig. 2) was attacled to the sigmoid flexure and was seen to spring from its mesantery. With some difficulty the growth was stripped off the bowel and enuclented from tha mesosigmoid. 'The raw arens were closed with catgut. 'There were metastatic growths lower down, along the rectum and behind the bladder. The operation lasted twenty-five ininutes.

At first the pratient did well, but he became distended and vomited and, though his howels moved and the pulse was never. very rapid, he died on the fiftl day. No autopsy was allowed. The pathologic report proved the tumor to be a round-coll

5. Bell and Yeoman: Brit. Mrad. Jour., 190)8, 11; 810.

6. Éler : láv. de méd. techuègue, Prague, 1008, 1, 38. 
sareoma. It was not so soit as such growths usually are and was definitely encapsuluted.

Since 1906, when Vancez reviewel the literature and in aldition to his own case, found seven others of mesenteric sarcoma, there have been reported two more. 'J'hese were both of mixed type. König's ease was that of a woman, 69 yeals of age, with ramosis, dyspmea, anasarca, ascites and a feeble pulse. He tapped and drew ofl 15 liters of fluid, locating a tmor of the shape and size of a child's head below the umbilicus. Operation revenled a tumor, partly solid and partly cystic, growing from the mesentery and loop of small intestine. Sxtirpation and resection of portion of bowel, with use of the Murphy button. Uneventful recovery followed. Microscopic examination showed the tumor to be a fibrosarcoma with large spindle cells. Marullazs presents the case of a man, nged (65, who had noticed swelling of the abdomen for two years. It was $108 \mathrm{~cm}$. in circumterence; the patient's general condition was poor, but no edema or ascites was present. $\Lambda$ t operation the large growth was found allerent to the stomach and transverse colon; resection was necessury for its removal and the patient died thirty-six hours afterward. 'The tumor' weighed over $6 \mathrm{~kg}$., and turned ont to be a myxosarcoma of the mesentery.

CASI: 3.-Blood Tumor of Mesentery-J. S. N., male, aged 60 , lad always been healthy up to a year ago, when he began to have pain in his righi side. He was treated in January, 1010, for what was thought to be appendicitis. He secmed to recover in four days and did not complain uguin for six months. At that time an enlargement was found in his right abdomen. He was then advised to seck surgical aid, but declined. For the past three months he had lost much flesh and strength, but had been almost free from neute pain.

Examination.-'llere was found in the riglit half of the nbiomen a swolling of the size of a grtuefruit, locnted almost on a level with the umbilicus. It was freely movable and seemed too fur forward for the kidney. A mesenteric growth was the most probuble condition.

Operation.-At Rex Hospital, Sept. 23, 1910: an incision in tho right rectus muscle exposed the hard nodular dark-red tumor, which grew in the mesentery of the ileum. It meronched so elosely on the intestimal wall and appearod so plainly malignnut that a lateral anastomosis was decided on. Nine inches of the bowel were removed along with a corresponding amount of mesentery down to its root. Tho putient did very well until the second day, when he suddenly developed pain, vomiting and dolirium without musual distenton, and lied probably from gangrene of the intestine. It was inpossible to make a post-mortem exanination. 'Jhe pathe logist's report, somewhnt of a nurprise, was as follows: "Sectioms from four different portions of tumor slow only young conmective tissue (an organizing elot). No indication of maligmaney" ( Jig. 3).

'This was a very difficult case. Resection was unAouhtedly demanded, and yet one hardly hoped to have suceess with it. The large $V$-shaped portion of mesentery, which liad to be excised. contained thrombosed blood-vessels, and they probably extended into apparently healthy areas berond the line of division. Malignant degeneration of a prexisting growth was certainly sugrested by the history. Possibly a slow-forming mesenteric thrombosis may have acrounted for the condition. There is a chronic thrombosis which gives rise 10 a large blood tumor between the layers of the mesentery, but it is much more rare than the acute form. Coilman," in speaking of this condition, says: "I have

7. Kinnlg: Milnehen. Med. Wehuschr., 1906, lili, 330.

8. Maruliaz: Arch. do méd. pxper. et d'anit. path., 1907, $x i x, 2033$

2. p. 140 . not made the diagnosis in any of them, nor do I expect to in the next." According to Ionglas, mesenterl b]ood-cysts may be due to injury with non-absorptioul of the effusion or to hemorrlage into a preformed cyst, as observed by limself. No sort of possible history on trammatism could be elicited in the case now being ${ }^{c}$ it sidered. So, in the light of the pathologic findings, has been put down as a blood-tumor of the mesentery: due most probably to a longr-continued process embolism and thrombosis.

Cass 4.-Round-Cell Sarcoma of Transverse Mesooolon- in Mrs. (i. W. J)., 52 years old, had her menopanse in 1904. June, 1910, she began to flow again and this went on almas continually to the time of her almission on Oet. 6,1910 . Som after the flow started, she felt an enlargement in her right sids necompanied by more or less pain. This lump continued of grow rupidly. During this time she lost weight, perlyaps pounds or more, and did not feel well at any time.

bxamination.-A very freely movable tumor, about long and 4 inches wide, soft in consistency, was found appar ently nttached near median line, below and just to the of the umbilicus; it could be pushed into the pelvic region night easily be mistaken for an ovarian cyst; the uterus normal; no growth on the cervix or on the endometrium; athexa showed no disease.

Operation.-Oet. 7, 1910, Rex Hospital: A long medis neision below the umbilieus revealed a mass rolled up in omentum. This was tied off and the tumor brought ap. was a growth (eviclently sarcomn) of the transverse mosocole and was shelled out without wounding the bowel or the me teric vessels. The bleeding was easily controlled. static nodules were felt in the pelvic cul-de-sac. onist reported "sarcoma-round-cell type."

The patient made an easy operative recovery and wont hou in two weeks. Before she left the hospital, the growth larger than it was when she came in, and she died at her hop ubout one month later.

There was no opportunity here to to any bowel reste tion owing to the secondary growths and the patiente enfeebled condition. 'The diagnosis was evident $\mathrm{fr}^{\prime}$ the rapidity of the tumor growth and the patient malignant appearance. It was a typical mesenteric bi coma (Fig. 4), its consistency being, as described the Bazin, "neither soft nor fluctuating, but pasty; dis surface not smooth but lobulated." It differed marked" from that of the second ease in this series, though the were of the same cellular type. The comments $n$ under that case will apply liere.

DIagnosis
One hesitates to lay down any rules whatever for the diagnosis of mesenteric tumors. It is often impossib to say beforehand that a reconizable enlargement rertainly a growth of the mesentery, and it may be rat to feel contented simply with deciding in most cases the surgical intervention is or is not indicated. Exploratos clingnosis is mquestionably the easiest and surest w8y A few principles for guilance, however, may be sf forth, these being based on the collected experience those who have in late years written on the subject looliglas is the only author who gives adequate conside ation to the diagnosis. I shall not here undertake labored presentation of symptoms and signs. will it be better profit to lay emplasis on those which point to an existing tumor as being possib mesenteric and to mention those conditions which min prevent confusion in distinguishing this growth some other neoplasm.

Subjective symptoms, if present, are not usually tinctive. Pain, which is the most important, is not

10. Bazin : 'These, Paris, 1007. 
to be attributed to the rare condition of a mesenteric dicular colic.. digestive troubles pation is nearly always the rule, and conmon, but sos, especially namsea and vomiting. are Intestinal so they are in many other conditions. result from the porion, volvulus and invagination may toms attending these of the tumor and give the symp-

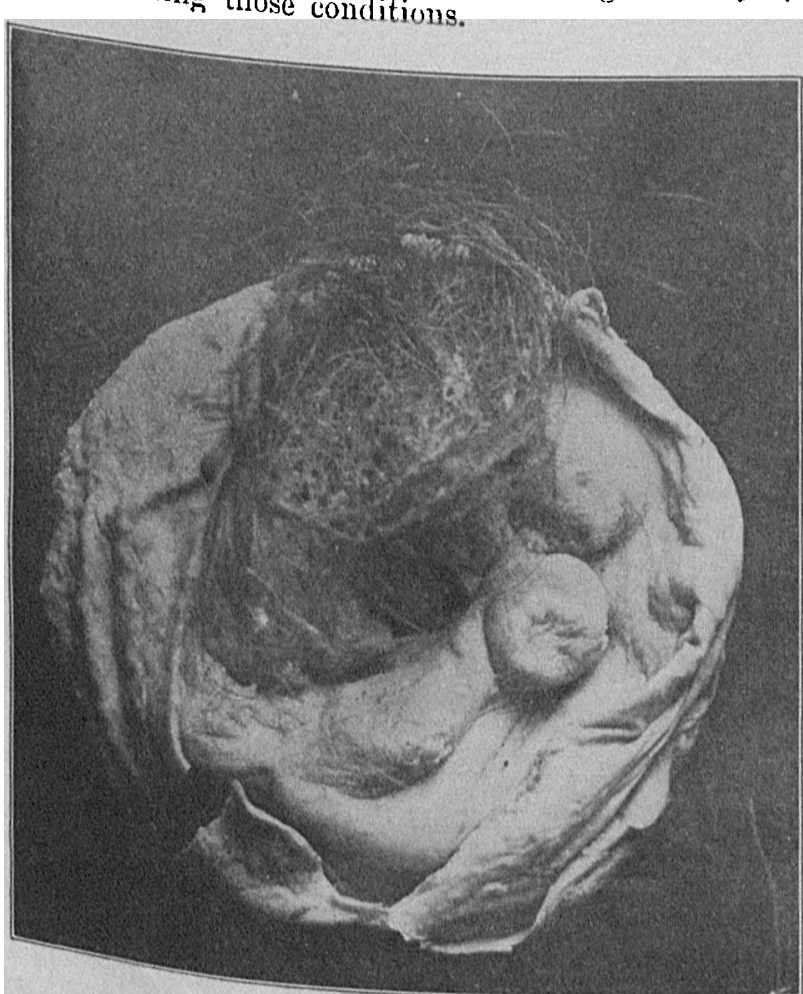

Fig. 1.-Dermold cyst of slgmold mesocolon.

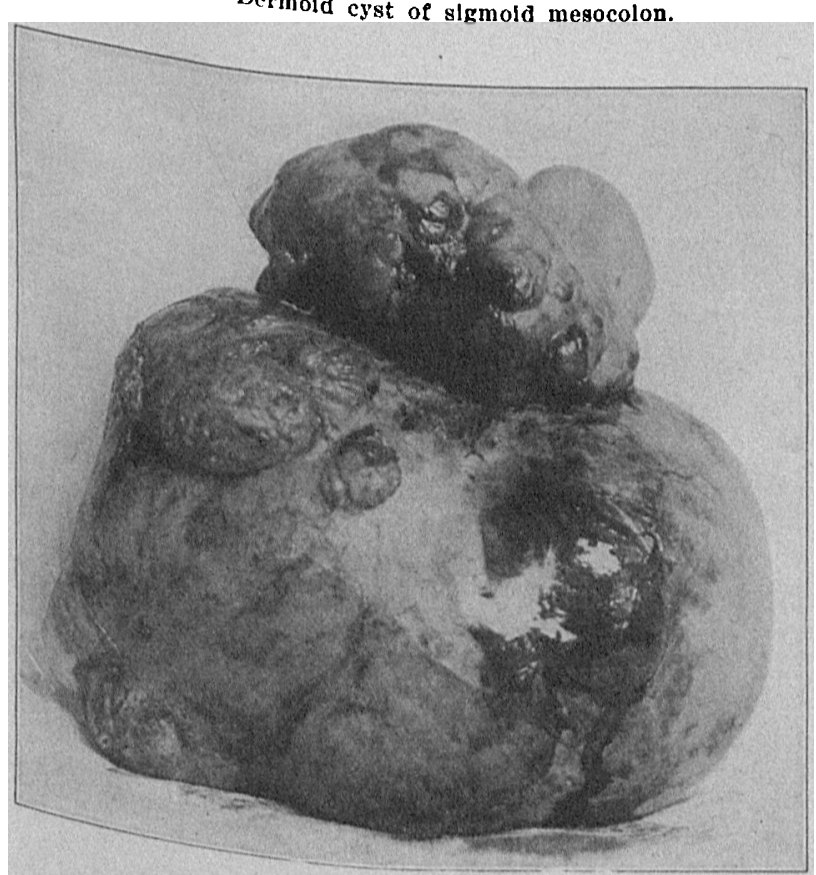

Fig. 2,- Sarcomn of sigmold mesocolon.

'Tlhe signs that most clearly give evidence of mesen-
teric tumols theip lelation concern their position, their mobility and of the middle liner organs. 'They are situated either' of the large bowe or far to either sicle over the comrse gle sign, as al. Free mobility is the most important h, as no other abclominal tumor will show this to the same dunree. The motion from side to side is especially malled. 'J'his may in a measure be diminished when the tumor is allowed to adrance to a great size. If it can be defermined that the tumor is separable from the solid visecra, a long step forward in the diagnosis will be male. Bazin speaks of a zone of resonance in front of or below the growth, and l)ouglas sugrests that this may be of value in oliminating pelvic tumors, if the patient is examined in the Jrendelenturgr posture. König regalds these as the important points: colicky pains radiating toward the mbilicus, the presence of bowel over the tumor and unusual mobility of the growth; and yet in his rase none of these signs was present. Ascites is one of the common complications.

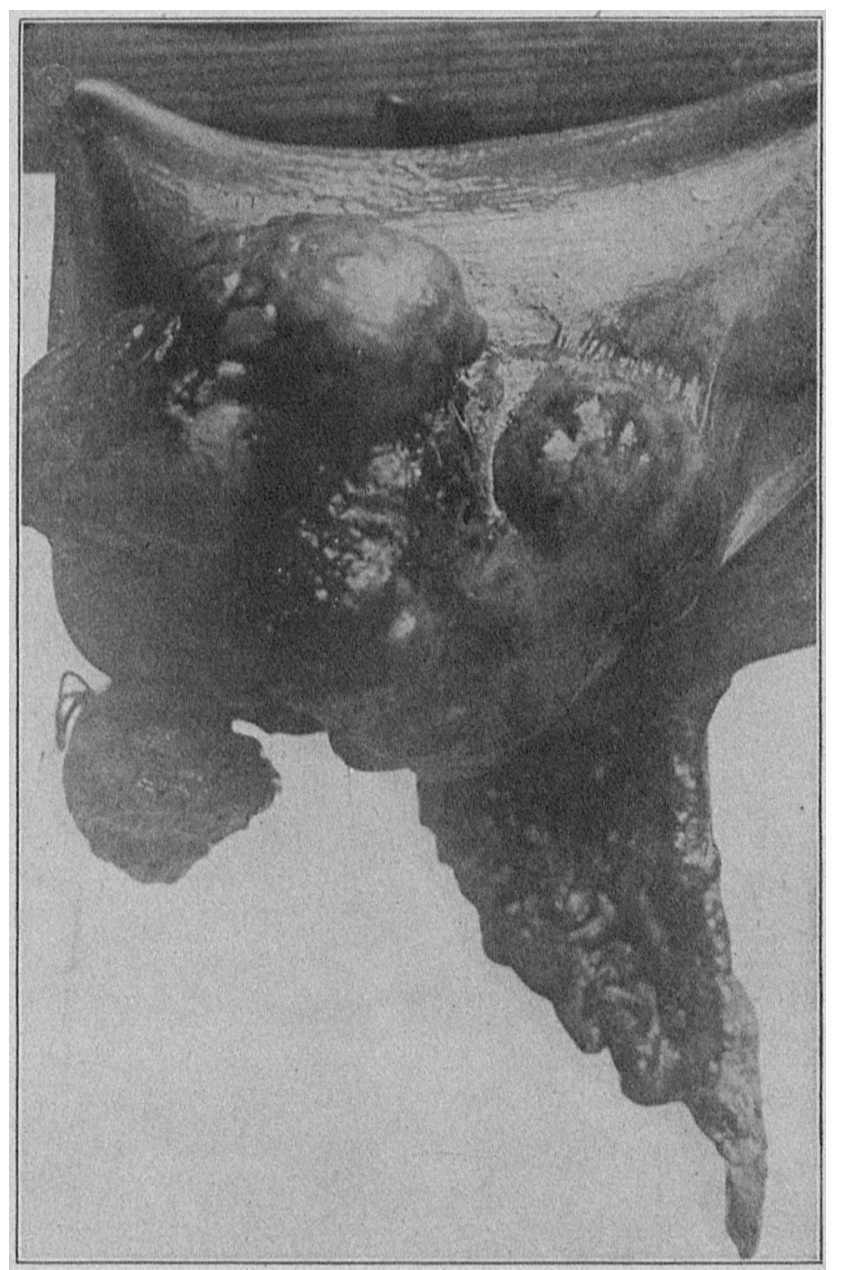

Fig. 3.-Blood tumor of mesentery.

'The differential diagnosis offers a wide field of problems. Chicf among these are ovarian cysts (which figured very strongly in the fourth (ase of my serjes), tumors of the liver, enlarements or displacements of the kidney, growths of the howel itsolf and cysts of the pancreas. It will hardly he expedient to go over the detailed characteristies of these combitions, as they are well known. One must keep them strongly in mind, however, when differentiating abdominal growths and be prepared to learu that the diagnosis of mesenteric tumors is not a simple aflair. 'Their very rarity is a reason for their being often overlooked. Reporting a filuremyxolipoma of the mesentery four years ngo, Wiesinger" remarked: "In the many thousand laparotomics

11. Welsinger: Mitt. a. d. IIuuburg. Stuatskrankunst., 1907, vil, 191. 
performed by the author for several rears, this is the only case he laas observed." ('ysts, more than the solid tumors, are likely to fumish soures of error in cliagnosis, from the meas of fluctuation usually present. These may be noted also in a lipoma when solt and of Jarge size, as mentioned by 'Jerrier. Bazin consider's the diagnosis of surconu rery difficult. Ite lays stress on "the rapidity of the growth. the cachesia and the more or less profoumd yelfow tint of cancer." Furthermore, he seems to alvise aspiratory puncture; this, he states, "will yield a cystic liquicl mixed with blood, which is not the case in a lipoma owing to its lack of vascular supply." 'The European surgeons. as a jule, write very unconcernedly of this method, as if it were their custom to aspirate all ablominal swellings lor diagnostic purposes-a practice which surely cannot be commended. Myxoma of the mesentery has been (onfounded with multilocular cyst of the ovary. Diagnosis must depend on excluding all possible evidence of the latter.

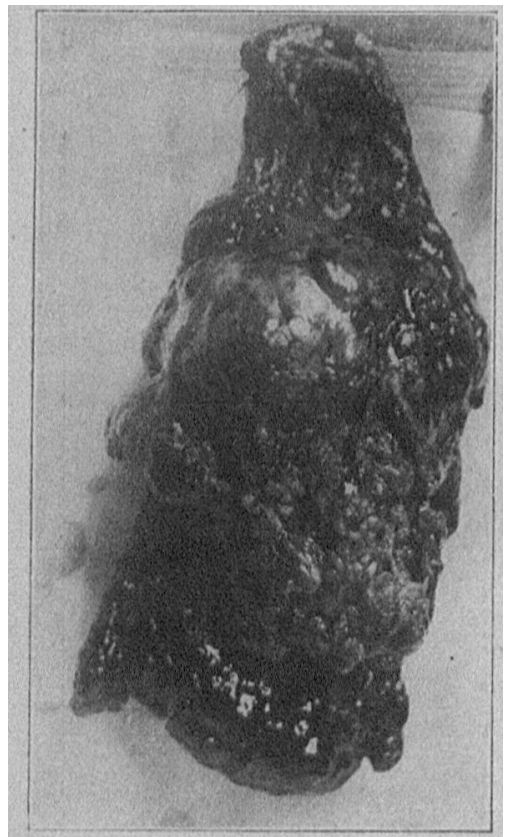

Fly. 4.--round-cell sarcoma of transycrse merocoton.

\section{I'ROGNOSIS}

The ontlook depends largely on the characfor of the growth. 1)anger results not only trom malignancy which may be present or imminent, but also from pressure due to the large size such tumors often attuin. Warly recognition and prompt lemoval are the remedies for both of these perils. ITnfortumately, late. dingnosis and turdy removal lave appeared to bo the order of the day. and thus the mortality las heen high. In 1 s.98 Beyonin collected notes of twenty-nine solicl tumors of the mesentery; of the pationts only fousteen survived the operation (mortality 51.8 per (ent.). Writers have since stated that our results are now better: but more recent reports do not show great improvement. $\checkmark$ ance, in 1906 , found twenty-seven cuses in the literature of the five years preceding and eleven of the patients died, a mortality of 40.7 per cent. Since llint clate, I have records of nine arses (including two lormoids) with three deaths; these, added to the four of my own, give a total of thirteen rases with six denths, or 45.1 per cent. mortality.

\section{OPEIRATIVE MIEIIODS}

In deciding on the proper procedure at the operation, one must have in mind three questions: First, is the tumor benign or malignant? Second, is it primary and isolated? Third, how much, if any, intestine is to be sacrificed in its extirpation? These points are often very difficult to determine. Since the last issue must dejend on the first two, the whole matter may be resolved into a decision on the indications in any given case for resection of the bowel. The mortality percontage will be closely concernod with this decision. In
Vances twenty-seven collected operations the intestine was resected thirteen times, with seven recoveries anll six deatlss; three of the tumors were sarcomata and all the patients died, while of the five fibromata cases onl! one resulted fatally. Obviously, one should be allale of the risk when electing to perform resection. Iot Murphy removed two feet of bowel, lexer six and il half feet, and shepherd seren feot eight inches. ull successfully, for benign growths. It must be comceded. of course, that the eases suitable for resection ale thost in which malignancy is evident or in which the gronth by its size or situation encroaches clangerously on the howel; both of these conditions will naturally be as: ciated witl a high deatlo-rate. Most assuredly the langer is increased by the removal of a portion of the bowel and the time consumed in the consequent amstomosis, on account either of shock, which has been givell as the cause of cleath in many of the operations, af of gungrene of the intestine, resulting from injury to he mutrient vessels, or of peritonitis, due to imperlect technic. We can heartily join Wiesinger, therefore, ill his advice to avoid resection wherever possible. and, as a sort of corollary, to be careful not to wound the blook-vessels of the mesentery in extippating the tumor. When that golden age shall arrive. in which the surgronl will be given early the privilege of examining and. if it seem wise, of operating on these patients promptly, then the vexations questions which have just clamed our attention may trouble us less and less.

\section{HAVI: WE AN IDEAL OPERATION FOli INTERNAT, HEMORIRHOIDS? \\ A NEW HEMORRIIOID CLAMP}

\section{A. B. CoOkE, M.D.}

NASIVILIE, TENX.

It is proper to acknowleclge, by way of introductions, that no operation in surgery of equal importance hals been performed as often or with as uniform success as that for the relief of internal hemornoirls. This rereol't is all the more remarkiable when the number and indiscriminate qualifications of the operators are considesed, and when the many diverse methods adrocated and princ" ticed are called to mind.

It is probably no exaggeration to eny that operationt by the ligature and clamp-and-cautery methods has beell performed hundreds of thousands of times under wert! imaginable condition, with a resulting mortality so 10 " as to be practically negligible. And the same is true of an alditional large number of cases in which the lonls list of modified and new methods have been emploperl. With this phenomenal history of achievement, it would seem that there is little ground for criticism either of the standard or of the more recently levised methods of operating. And let me lasten to add that such is $10^{\circ}$ the purpose of the present brief paper, except in so fir as the several methods fail to conform to the accepter principles and precepts of modern surgery.

Now what are those principles and precepts as appliad to the surgery of internal hemorrhoids? Among the more important are: (1) complete hemostasis. (2) immediate closure of the operative wounds, (3) $\mathrm{pic}^{\mathrm{e}^{-}}$ servation of the function of the parts, (4) permanenc? of eure, and (5) due consideration of the factors of safety, simplicity of technic, time required for recovert: and the amount of post-operative pain. Antisepsis is not included in the list for the reason that at the present 